\title{
Including GHG emissions from mangrove forests LULUC in LCA: a case study on shrimp farming in the Mekong Delta, Vietnam
}

\author{
Natasha Järviö $^{1,2}$ (D) • Patrik J. G. Henriksson ${ }^{3,4}$ • Jeroen B. Guinée ${ }^{1}$
}

Received: 6 March 2016 / Accepted: 18 April 2017 / Published online: 23 May 2017

(C) The Author(s) 2017. This article is an open access publication

\begin{abstract}
Purpose Mangrove forests have been recognized as important regulators of greenhouse gases (GHGs), yet the resulting land use and land-use change (LULUC) emissions have rarely been accounted for in life cycle assessment (LCA) studies. The present study therefore presents up-to-date estimates for GHG emissions from mangrove LULUC and applies them to a case study of shrimp farming in Vietnam.

Methods To estimate the global warming impacts of mangrove LULUC, a combination of the International Panel for Climate Change (IPCC) guidelines, the Net Committed Emissions, and the Missed Potential Carbon Sink method were used. A literature review was then conducted to characterize the most critical parameters for calculating carbon losses, missed sequestration, methane fluxes, and dinitrogen monoxide emissions.

Results and discussion Our estimated LUC emissions from mangrove deforestation resulted in $124 \mathrm{t} \mathrm{CO}_{2} \mathrm{ha}^{-1}$ year ${ }^{-1}$, assuming IPCC's recommendations of $1 \mathrm{~m}$ of soil loss, and
\end{abstract}

Responsible editor: Matthias Finkbeiner

Electronic supplementary material The online version of this article (doi:10.1007/s11367-017-1332-9) contains supplementary material, which is available to authorized users.

Jeroen B. Guinée

guinee@cml.leidenuniv.nl

1 Institute of Environmental Science CML, Leiden University, Einsteinweg 2, 2333 CC Leiden, Netherlands

2 Finnish Environment Institute (SYKE), Mechelininkatu 34a, FI-00260 Helsinki, Finland

3 Stockholm Resilience Centre, Stockholm University, Kräftriket 2B, 11419 Stockholm, Sweden

4 WorldFish, Jalan Batu Maung, 11960 Penang, Malaysia
96\% carbon oxidation. In addition to this, $1.25 \mathrm{t}$ of carbon would no longer be sequestered annually. Discounted over 20 years, this resulted in total LULUC emissions of $129 \mathrm{t}$ $\mathrm{CO}_{2} \mathrm{ha}^{-1}$ year $^{-1}(\mathrm{CV}=0.441$, lognormal distribution $(\ln ))$. Shrimp farms in the Mekong Delta, however, can today operate for 50 years or more, but are $1.5 \mathrm{~m}$ deep (50\% oxidation). In addition to this, Asian tiger shrimp farming in mixed mangrove concurrent farms (the only type of shrimp farm that resulted in mangrove deforestation since 2000 in our case study) resulted in $533 \mathrm{~kg}$ methane and $1.67 \mathrm{~kg}$ dinitrogen monoxide per hectare annually. Consequently, the LULUC GHG emissions resulted in 184 and $282 \mathrm{t} \mathrm{CO}_{2}$-eq t $\mathrm{t}^{-1}$ live shrimp at farm gate, using mass and economic allocation, respectively. These GHG emissions are about an order of magnitude higher than from semi-intensive or intensive shrimp farming systems. Limitations in data quality and quantity also led us to quantify the uncertainties around our emission estimates, resulting in a $\mathrm{CV}$ of between 0.4 and 0.5 .

Conclusions Our results reinforce the urgency of conserving mangrove forests and the need to quantify uncertainties around LULUC emissions. It also questions mixed mangrove concurrent shrimp farming, where partial removal of mangrove forests is endorsed based upon the benefits of partial mangrove conservation and maintenance of certain ecosystem services. While we recognize that these activities limit the chances of complete removal, our estimates show that large GHG emissions from mangrove LULUC question the sustainability of this type of shrimp farming, especially since mixed mangrove farming only provide $5 \%$ of all farmed shrimp produced in Vietnam.

Keywords Aquaculture - Carbon footprint - Deforestation . Land use $\cdot$ Land-use change $\cdot$ LCA $\cdot$ Mangrove $\cdot$ Shrimp . Vietnam 


\section{Introduction}

Mangrove forests are among the most productive tropical ecosystems in the world, with net annual production exceeding that of most terrestrial forests (Twilley et al. 1992; Eong 1993; Kauffman et al. 2011; Mcleod et al. 2011). They have also been recognized for their importance in providing valuable ecosystem services (Rönnbäck 1999; Hong and Dao 2004; Bouillon et al. 2008; Kristensen et al. 2008). These include coastline protection from storms, erosion, saline intrusion, and pollution (Rönnbäck 1999; Hong and Dao 2004), supporting and maintaining biodiversity, and provision of energy to adjacent ecosystems (Rönnbäck 1999; Kristensen et al. 2008). More recently, the important role of mangrove forests in the capture and sequestration of carbon dioxide $\left(\mathrm{CO}_{2}\right)$ from the atmosphere has gained increasing recognition, as mangrove forests, unlike terrestrial forests, do not become saturated with carbon, and sediments accrete vertically (Mcleod et al. 2011). The sequestration of carbon in sediments and the depth of the soil may therefore continue to increase over millennia (Eong 1993; Duarte et al. 2005; Mcleod et al. 2011). Their organically rich soils, typically extending downward over several meters, make up one of the largest organic carbon reserves in the terrestrial biosphere (Chmura et al. 2003; Lovelock 2008). Sequestration rates have been estimated at between 228 and $766 \mathrm{t} \mathrm{ha}^{-1}$ year $^{-1}$ (Kauffman et al. 2011; Lundstrum and Chen 2014). Hypoxic conditions and the lack of other high-energy oxidants, in combination with a paucity of fungi, limit the opportunity for degradation, thereby providing good conditions for long-term storage of carbon (Middleton and McKee 2001). This, together with high biomass burial rates, the high potential age of mangrove trees, and a slow turnover rate, results in carbon storage rates relevant at global scales (Duarte et al. 2005; FAO 2007).

Despite the recognition of their ecological value, mangrove forests worldwide are under threat from land-use change, with annual deforestation rates between 0.7 and $2.1 \%$, far exceeding those of inland tropical forests (Murray et al. 2012). For example, countries like Thailand and Vietnam, which harbor large shares of the global mangrove forests, have been reported to have lost $43 \%$ of their mangrove forests since 1980 and are to be at risk of losing an additional third of the remaining forests over the next two decades unless their governments improve the protection of mangrove areas (WWF 2013). Expansions of aquaculture and especially shrimp farming have been held accountable for $30 \%$ of the mangrove loss in SE Asia (Richards and Friess 2015). This as most shrimp species are most productive when farmed in brackish water, which often results in the establishment of shrimp ponds in coastal regions where they compete with mangrove forests (Béland et al. 2006; Murray et al. 2012). Given an annual growth rate of the shrimp farming in Asia of $8 \%$ over the last decade, alongside continued agricultural and urban growth, the future will surely pose additional threats to the mangrove ecosystems in the region (FAO FishstatJ 2014; Richards and Friess 2015).

Already in 2007, Milà i Canals called for more papers on dealing with land use-related greenhouse gas emissions (GHG) in life cycle assessment (LCA), while growing scientific concerns about mangrove deforestation have been accumulating with regards to aquaculture and mangrove deforestation. Despite this, few aquaculture LCAs have included mangrove land use and land-use change (LULUC) emissions to date (Henriksson et al. 2012). The International Panel for Climate Change (IPCC) published guidelines for the estimation of carbon dioxide emissions from land-use change of mangrove forests caused by aquaculture in 2013 (IPCC 2014). These guidelines, however, have their limitations, as they provide no guidance on carbon or methane $\left(\mathrm{CH}_{4}\right)$ or dinitrogen monoxide $\left(\mathrm{N}_{2} \mathrm{O}\right)$ emissions regarding land use for aquaculture purposes. This means that the continuous high rate of carbon burial into the soil of mangrove forests is not considered, although this is what distinguishes these forests from other terrestrial forests (Duarte et al. 2005; FAO 2007; Mcleod et al. 2011), and emissions of two other potent GHGs often go unaccounted for.

Following criticism, shrimp farming practices have been improved in many countries: new farms are now established outside mangrove areas, productivity has increased, and better farm management has allowed farms to continue operations over longer time periods without having to relocate due to sediment build-up (Lebel et al. 2002, 2010). Despite this, concerns about the conversion of mangrove forests into shrimp farms were again raised by Prof. JB Kauffman during the 2012 meeting of the American Association for the Advancement of Science (Stokstad 2012). During this meeting, Kauffman highlighted that the carbon dioxide emissions resulting from mangrove deforestation amounted to $198 \mathrm{~kg}$ $\mathrm{CO}_{2}$ per $100 \mathrm{~g}$ of shrimp tails. While this definitely raises concerns, some assumptions regarding the location of newly established shrimp farms, pond productivity, and pond lifespan were later called into question by the Global Aquaculture Alliance (Global Aquaculture Alliance 2012).

Given the controversies surrounding the emissions resulting from LULUC due to mangrove deforestation for shrimp farming and the clear lack of its resulting emissions in LCAs, the present study aimed to present up-to-date GHG emission estimates for mangrove LULUC. We also demonstrate our accounting methods using shrimp farming as a case study. To put these emissions into context, we also used the LCA framework (ISO 2006), allowing GHG emissions from semi-intensive and intensive shrimp production chains to be considered as a reference. Using the LULUC emission factors and production data for shrimp farming in the Mekong Delta of Vietnam, we estimated the contributions of mangrove 
LULUC emissions relative to the overall carbon footprint of shrimp farming.

In order to address our identified shortcoming in literature, each section first aims to quantify the GHG emission from generic mangrove deforestation using IPCC assumptions, followed by its application to the shrimp case study. Section 2 thus first identifies the relevant parameters for calculating the GHG emissions from mangrove deforestation, including changes in carbon stocks as visualized in Fig. 1, and characteristics of $\mathrm{CH}_{4}$ and $\mathrm{N}_{2} \mathrm{O}$ fluxes (Section 2.3). This is followed by details about the case study in Section 2.3. Section 3 subsequently presents the ranges of results derived from literature for each parameter and summarizes these as easy-to-use LCA parameters including uncertainty estimates. These values were also modified for the case study in Section 3.3 to quantify the impact of shrimp farming in previous mangrove areas in terms of $\mathrm{CO}_{2}$-equivalents $\left(\mathrm{CO}_{2}\right.$-eq). Finally, in the discussion and conclusion, we expand on the implications of our findings.

\section{Materials and methods}

The carbon stock dynamics resulting from mangrove deforestation are illustrated in Fig. 1 with each, before (time $<0$ ) and after (time $>0$ ) the establishment of shrimp ponds. Before land-use change (LUC), above- and below-ground and litter $\mathrm{C}$ stocks remain approximately constant over time. It is assumed that, in general, primary mangrove forests are in equilibrium and are therefore not storing more biomass over time (IPCC 2006). However, the carbon in the mangrove soil will increase over time due to a continuous carbon burial rate, as seen in Fig. 1. LUC is a consequence of the establishment of the shrimp farm during its first year by removing the aboveand below-ground vegetation and excavation of ponds, resulting in the loss and oxidization of all carbon stored in the above- and below-ground parts of the mangrove, in the litter and in part of the soil. The resulting emissions are therefore allocated to the LUC activity $(\beta)$. This also means that all emissions that occur during later years, i.e., oxidization of the carbon in the soil over time $(\delta)$, are considered to be a

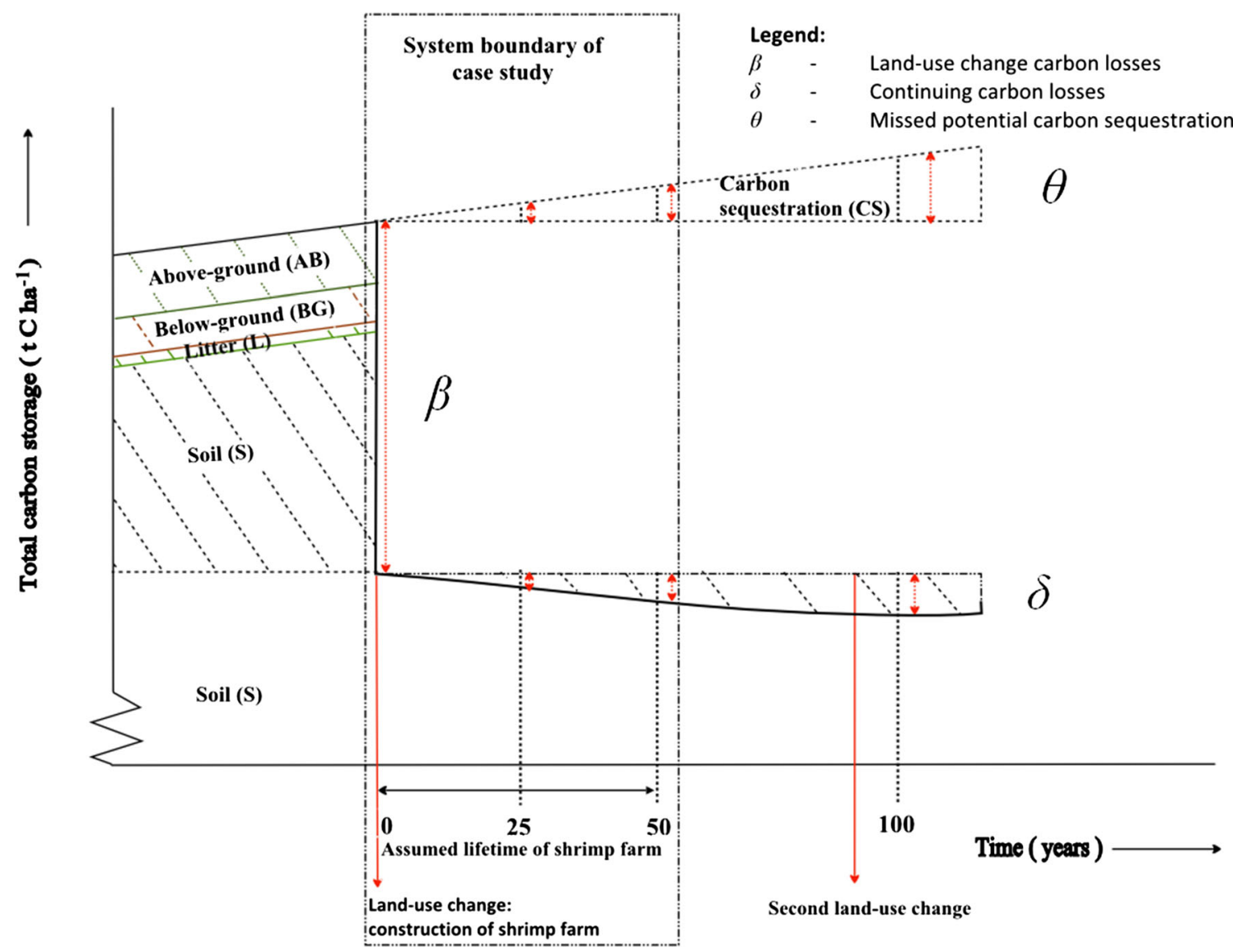

Fig. 1 To calculate $\mathrm{CO}_{2}$ emissions resulting from mangrove LULUC, this figure depicts the important processes behind LUC ( $\beta$ and $\delta$ ) and LU $(\theta) \mathrm{CO}_{2}$ emissions from mangrove forests. The LUC carbon losses consist of the above-ground (AG), below-ground (BG), soil (S), and litter (L) $\mathrm{CO}_{2}$ emissions, regardless of when in time they occur (i.e. the oxidization of carbon in the soil over time, $\delta$ ) (IPCC 2006; Cederberg et al. 2011). LU
$\mathrm{CO}_{2}$ emissions are based on the mangrove's potential carbon sequestration rates. The LUC carbon losses $(\beta$ and $\delta$ ) are factual losses that can be measured at the point when they occur. The emissions resulting from $\mathrm{LU}(\theta)$, on the other hand, are based on potential sequestration rates 
consequence of the initial LUC and assigned to the activity and year of the LUC (IPCC 2006; Cederberg et al. 2011). During the time in which the farmer uses the land for shrimp farming, the area originally comprising the mangrove forests no longer takes up any carbon. Aquaculture ponds and other land uses will also result in altered methane and dinitrogen oxide emissions. These are the LU emissions and they are the result of the missed carbon sequestration $(\theta)$, anoxic methane formation, and nitrogen volatilization.

\subsection{Carbon dioxide LULUC emissions from mangrove deforestation}

In the present study, $\mathrm{CO}_{2}$ emissions due to $\mathrm{LUC}$ of coastal wetlands with mangrove as vegetation, to a new land use were calculated using a combination of the Net Committed Emissions (NCE) method by Cederberg et al. 2011 and the IPCC guidelines (2006, 2014). The NCE method (Cederberg et al. 2011) offered us a way to include carbon stock changes resulting from LUC by comparing the carbon stocks before LUC with those after LUC, while we used the reference land use and guidelines provided by the IPCC (2006), such as a 1-m default soil depth and 96\% of carbon oxidized (IPCC 2014). We used the Missed Potential Carbon Sink method proposed by Schmidinger and Stehfest (2012) as inspiration to evaluate the potential carbon storage missed as a result of land use (LU) [see Electronic Supplementary Material (ESM 1) for a full analysis of all methods]. The "missed potential carbon sequestration" is important to take into account, as mangrove forests left standing would continue to sequestrate substantial amounts of carbon in the soil (Eong 1993; Duarte et al. 2005; Mcleod et al. 2011). The missed potential carbon sequestration is therefore based on the mangrove carbon sequestration rate.

The total emissions were annualized and not amortized, in line with the IPCC guidelines. Many guidelines set a default value of the particular number of years, or timeframe, over which the LULUC $\mathrm{CO}_{2}$ emissions should be annualized, usually ranging from 20 to 30 years (ISO 2006; FAO 2007; Cederberg et al. 2011). The IPCC (IPCC 2006) uses a default value of 20 years, based on the argument that this is the time required for carbon stocks to reach equilibrium. Noteworthy is that the assumed timeframe greatly influences estimated LULUC emissions.

The total change in the carbon balance resulting from mangrove LULUC can thus be summarized as follows:

$\Delta C_{\mathrm{TOTAL} i}=\Delta C_{L U C i}+\Delta C_{L U i}$

where

$\Delta C_{\text {TOTALi }}$ is the total carbon loss resulting from the establishment of land use $i$ during the timeframe ( $\mathrm{C}^{-1}$ ) (multiply $\mathrm{C}$ with 3.667 for $\mathrm{CO}_{2}$ )
$\Delta C_{L U C i}$ is the carbon loss caused by land-use change for land use $i$ (regardless of when in time they occur) ( $\mathrm{t} \mathrm{C} \mathrm{ha}^{-1}$ )

$\Delta C_{L U i}$ is the total carbon loss caused by land use $i\left(\mathrm{t} \mathrm{C} \mathrm{ha}^{-1}\right)$

$i$ is the new land use (i.e., shrimp farming)

The total carbon loss caused by land-use change $\left(\Delta C_{L U C i}\right)$ can, in turn, be calculated using Eq. (1) (initial letters $\beta, \delta$, or $\theta$, refer to Fig. 1):

$\Delta C_{L U C i}=\Delta \beta_{A G i}+\Delta \beta_{B G i}+\Delta \beta_{L i}+\left(\Delta \beta \delta_{S i}{ }^{*} S O_{i}\right)$

where

$\Delta \beta_{A G i}$ is the change in the above-ground carbon stock caused by land-use change ( $\mathrm{t} \mathrm{ha}^{-1}$ )

$\Delta \beta_{B G i}$ is the change in the below-ground carbon stock caused by land-use change ( $\mathrm{t} \mathrm{ha}^{-1}$ )

$\Delta \beta_{L i}$ is the change in the litter carbon stock caused by landuse change ( $\mathrm{t} \mathrm{Cha}^{-1}$ )

$\Delta \beta \delta_{S i}$ is the change in the soil carbon stock caused by land use change ( $\mathrm{t} \mathrm{Cha}^{-1}$ ) (default depth of $1 \mathrm{~m}$; IPCC 2014)

$\mathrm{SO}_{i}$ is the amount of carbon in soil exposed to oxidation, in percentage ( $\mathrm{t} \mathrm{C} \mathrm{ha}^{-1}$ ) (default value of 96\%; IPCC 2014)

The total missed carbon sequestration caused by land use $\left(\Delta C_{L U i}\right)$ could, in turn, be calculated using Eq. (3):

$\Delta C_{L U i}=\Delta \theta_{M P i}{ }^{*} T$

where

$\theta_{M P i}$ is the missed potential of carbon that would have been sequestered if the mangrove was left standing $\left(\mathrm{t} \mathrm{C} \mathrm{ha}^{-1}\right.$ year $\left.^{-1}\right)$

$T$ is the timeframe, in years (default of 20 years; IPCC 2006)

The parameters identified for calculating the $\mathrm{CO}_{2}$ emissions in Eqs. (2) and (3) were identified through a literature review (see Table 1 for the definitions). Articles were selected by searching for the keywords "mangrove", "carbon", "emissions", "storage", "soil", "land-use change", and "primary production" in Google Scholar (search carried out on April 21, 2015). To establish uncertainty parameters for the resulting $\mathrm{CO}_{2}$ emissions from mangrove LULUC, ranges of results were produced over 10,000 Monte Carlo iterations. The Monte Carlo results were generated using CMLCA v5.2.

\subsection{Methane and dinitrogen monoxide emissions from aquaculture farming}

Only recently have estimates been made about methane $\left(\mathrm{CH}_{4}\right)$ and nitrous oxide $\left(\mathrm{N}_{2} \mathrm{O}\right)$ emissions resulting from aquaculture (Hu et al. 2012; Astudillo et al. 2015). No study to our knowledge has, however, measured these emissions from aquaculture activities on converted mangrove forest. Instead, we therefore collected a range of available values reported for both standing mangrove and conventional aquaculture. 
Table 1 Definition of parameters relevant to the calculation of the carbon footprint of mangrove LULUC

\begin{tabular}{|c|c|c|}
\hline Parameter & Alternative names & Description \\
\hline $\mathrm{AG}$ & Above-ground carbon & $\begin{array}{l}\text { The above-ground carbon includes all carbon found in the live } \\
\text { biomass located above the ground, which includes the stems of the } \\
\text { trees, their branches, and their leaves. }\end{array}$ \\
\hline BG & Below-ground carbon & $\begin{array}{l}\text { Below-ground carbon includes all carbon found in live biomass } \\
\text { located below the ground, which not only includes the carbon in } \\
\text { actual below-ground root biomass but also the prop roots which } \\
\text { are in fact located above the ground. It does not include the carbon } \\
\text { found in soil. }\end{array}$ \\
\hline S & Soil/sediments & $\begin{array}{l}\text { Soil carbon is the carbon stored in the soil. Soil contains dead organic } \\
\text { material derived from decomposed plants and animals, and } \\
\text { inorganic matter that have built up over time. Per IPCC, a soil } \\
\text { depth of } 1 \mathrm{~m} \text { should be considered, but for the shrimp case study, } \\
1.5 \mathrm{~m} \text { was adopted based upon the average depth reported by } \\
\text { farmers. }\end{array}$ \\
\hline $\mathrm{L}$ & Litter & $\begin{array}{l}\text { Litter is all dead biomass including material that was previously part } \\
\text { of the bulk of biomass in the net primary production. Litter C } \\
\text { stocks include both above- and below-ground litter stocks. Litter } \\
\text { can include just leaves, but also slash, stumps, dead trees, } \\
\text { stipulates, reproductive parts, branches, and debris. }\end{array}$ \\
\hline $\mathrm{CS}$ & $\begin{array}{l}\text { (Missed potential for) } \\
\text { carbon sequestration }\end{array}$ & $\begin{array}{l}\text { Carbon burial to soil refers to the process of the carbon being buried } \\
\text { in the sediments. This is caused by the production of } \\
\text { carbon-containing litter in the ecosystem and the import of carbon } \\
\text { from adjacent ecosystems. Part of this carbon gets trapped into the } \\
\text { sediments, where it can remain in the soil for centuries. In the } \\
\text { literature, carbon sequestration is often used interchangeably with } \\
\text { carbon burial rates (Mcleod et al. 2011). Both refer to the } \\
\text { long-term storage of } \mathrm{CO}_{2} \text { from the atmosphere and its deposition } \\
\text { in reservoirs, where long-term refers to centuries to millennia } \\
\text { (Mcleod et al. 2011). Missed potential carbon sequestration refers } \\
\text { to the amount of carbon sequestration not realized due to } \\
\text { mangrove forest being converted to, i.e., shrimp ponds. }\end{array}$ \\
\hline
\end{tabular}

\subsection{Case study: shrimp farming in the Mekong Delta, Vietnam.}

To illustrate the potential GHG emissions from mangrove LULUC, we applied the proposed method in combination with data collected for 200 randomly selected shrimp farmers in Vietnam between 2011 and 2012 as part of the EU FP7 SEAT project (European Commission within the Seventh Framework Programme, Sustainable Ethical Aquaculture Trade) (www.seatglobal.eu) (Murray et al. 2013; Henriksson et al. 2015). Vietnam is one of the world's leading exporters of shrimp, with a significant growth in production since the mid-1980s. Most of the shrimp farms are in the Mekong Delta, and specifically the province of $\mathrm{Ca} \mathrm{Mau}$. This area also harbors about one third of the remaining mangrove forests of Vietnam (Jonell and Henriksson 2014). These mangrove forests also support mixed mangrove concurrent farming of Asian tiger shrimp (Penaeus monodon), an extensive farming practice with minimal to no external inputs that takes place within the mangrove forest. The original intent of this practice was to provide partial protection of mangrove forests by allowing families to use up to $30 \%$ of the land and surface water to generate income, thereby preventing complete deforestation (McNally et al. 2010). Besides the mixed mangrove farms, four other kinds of shrimp farming practices have been identified in Mekong delta; these and their main difference are listed in Table 2 (FAO 2005; Phan et al. 2011). For a more elaborate explanation about the differences in farming practices identified during the SEAT project, we refer to Phan et al. (2011) and Henriksson et al. (2015).

Shrimp farms are established by removing the vegetation (or part of it) or transforming the land from alternative land uses (commonly rice paddies), followed by digging of ponds. Although the depth of ponds can vary slightly between farming practices, an average pond depth of $1.5 \mathrm{~m}$ was assumed (Phan et al. 2011; Murray et al. 2013) meaning that $1.5 \mathrm{~m}$ of soil carbon was assumed to be lost. Mangrove forests have shallow root systems, which means that most of the roots are found in the upper $0.7 \mathrm{~m}$ of the soil (National Oceanic and Atmospheric Administration-Earth System 2010). All mangrove roots were therefore considered lost during pond construction. The exact amount of carbon that is removed as soil is more difficult to predict, as some of the sediments normally are used to construct pond walls, where the carbon would 
Table 2 Five common Asian tiger shrimp farming practices identified in Vietnam, with data from Murray et al. (2013), and in brackets from Phan et al. (2011), and the Food and Agriculture Organization of the United Nations (FAO 2005)

\begin{tabular}{llcl}
\hline System & Crops year & $\begin{array}{l}\text { t shrimp crop } \mathrm{ha}^{-1} \\
\text { water surface area }\end{array}$ & $\begin{array}{l}\mathrm{t}_{\text {shrimp ha }}^{-1} \\
\text { water surface } \text { area year }^{-1}\end{array}$ \\
\hline Intensive & 1 & $7.6 \pm 7.0$ & $7.6(10-17.5)$ \\
Semi-intensive & 1.15 & $4.4 \pm 4.5$ & $6.6(2-4)$ \\
Improved extensive & 1.25 & $0.25 \pm 0.29$ & $0.3(1-1.2)$ \\
Mixed mangrove concurrent & 1 & $0.13 \pm 0.12$ & $0.13(0.25-0.30)$ \\
\hline
\end{tabular}

degrade under hypoxic conditions (Mungkung 2005). Carbon loss due to soil removal consequently depends on many factors, including the depth of the pond, the age of the shrimp farm and wall, the size and surface area of the wall, and the fate of the sediments after the shrimp farm has been abandoned. It has been conservatively assumed in previous studies that about half of the carbon is oxidized (Eong 1993), and this assumption was adopted in the calculations for the present study.

To identify which types of shrimp farms result in mangrove LULUC, the GPS coordinates from the SEAT survey were evaluated using satellite images, comparing land use before and after the establishment of the farms, and categorized based upon prior land use and farming practices. While the SEAT dataset also includes farmer testimonies on prior land use, these responses were sometimes biased due to shifts in farm ownership and to Vietnamese shrimp farmers being aware of the controversy surrounding mangrove deforestation. Satellite images from Google Earth (Google 2013), the Global Land Cover by National Mapping Organizations (ISCGM 2003), and a map showing global mangrove distribution developed by Giri et al. (2011) were therefore used to supplement the farmers' responses.

The combination of three sources of satellite imagery provided information about the historic land use going back to the year 2000, before any of the analyzed shrimp farms had been established. Present mangrove cover was estimated by locating the farms on Google Earth, drawing boundary lines around the pond, and estimating the percentage of mangrove within this boundary. All mangrove located within the boundary of the shrimp pond were considered to be part of the pond (for an example and description of mixed mangrove concurrent shrimp farm, see the study by Jonell and Henriksson 2014). Consequently, the difference in mangrove cover before and after pond establishment could be determined for the different types of shrimp farming (for more details on the method used, see the ESM 1 of this article). Lowresolution images were excluded from further analyses.

After the shrimp farming systems that resulted in mangrove deforestation had been identified, the resulting GHG emissions from LULUC were calculated. The functional unit of the shrimp production was defined as $1 \mathrm{t}$ of live weight shrimp at farm. The average lifetime of shrimp farms was deemed as the most suitable timeframe, as all shrimp produced contribute equally to the mangrove forest LULUC. A timeframe of 50 years, the current life expectancy of a shrimp farm, was therefore used to annualize emissions (Jonell and Henriksson 2014) (see ESM2 for calculations).

\section{Results}

\subsection{Carbon dioxide emissions per hectare of deforested mangrove}

Parameters for Eqs. (2) and (3) are presented in Table 3. Due to the limited literature values, studies describing globally diverse mangrove forests were used. Our estimated emissions can therefore be used as proxies for mangrove LULUC emissions worldwide, but also entail large uncertainties (see ESM 1).

Given the presented ranges, all distributions except litter $\mathrm{C}$ (assumed as normally distributed) were assumed to be lognormal $(\ln )$. For default mangrove removal annualized over 20 years, as recommended by the IPCC, the resulting $\mathrm{CO}_{2}$ emissions were $129 \mathrm{t} \mathrm{CO}_{2} \mathrm{ha}^{-1}$ year ${ }^{-1}$ $(\mathrm{CV}=0.441, \mathrm{ln})$, while if the emissions were annualized over 50 years, the annual emission was estimated to $54 \mathrm{t}$ $\mathrm{CO}_{2} \mathrm{ha}^{-1}$ year $^{-1}(\mathrm{CV}=0.424, \ln )$. The ESM 2 gives a more detailed report on the results of the literature study and the calculated results.

\subsection{Methane and dinitrogen monoxide emissions per hectare of mangrove converted to aquaculture pond}

Studies on intact mangrove suggest that methane fluxes in estuarine wetlands, including mangrove forests, are remarkably low due to the inhibition of methanogenesis by sulfates (Kristensen et al. 2008; Howe et al. 2009). Deforestation and fish farming undoubtedly increase these gas fluxes, an assumption also supported by Astudillo et al. (2015) (Table 4). We consequently adopted Astudillo et al.'s (2015) estimate $\left(533 \mathrm{~kg} \mathrm{CH}_{4}\right.$ $\mathrm{ha}^{-1}$ year $^{-1} ; \mathrm{CV}=0.4, \mathrm{ln}$ ) as a worst-case scenario. As for dinitrogen monoxide, emissions are more dependent 
Table 3 Overview of average values of mangrove forest carbon stocks

\begin{tabular}{|c|c|c|c|c|c|}
\hline Reference & Parameter & Median & $\mathrm{CV}$ (distribution) & Range & $n$ \\
\hline $\mathrm{AG}$ & Above-ground $\mathrm{C}$ stock $\left(\mathrm{t} \mathrm{C} \mathrm{ha}{ }^{-1}\right)^{\mathrm{a}}$ & 131 & $0.462(\ln )$ & $49.5-261$ & 9 \\
\hline BG & Below-ground $\mathrm{C}$ stock $\left(\mathrm{t} \mathrm{C} \mathrm{ha}{ }^{-1}\right)^{\mathrm{b}}$ & 80 & $1.525(\ln )$ & $9.61-410$ & 8 \\
\hline S & Soil $\mathrm{C}$ stock per $1.5 \mathrm{~m}$ of depth $\left(\mathrm{t} \mathrm{C} \mathrm{ha}{ }^{-1}\right)^{\mathrm{c}}$ & 724 & $0.595(\ln )$ & $186.15-1575$ & 8 \\
\hline $\mathrm{L}$ & Litter loss $\mathrm{C}$ stocks $\left(\mathrm{t} \mathrm{C} \mathrm{ha}^{-1}\right)^{\mathrm{d}}$ & 4.03 & $0.477(\mathrm{n})$ & $0.15-7$ & 12 \\
\hline $\mathrm{CS}$ & $\mathrm{C}$ Missed potential $\left(\mathrm{t} \mathrm{C} \mathrm{ha}^{-1} \text { year }^{-1}\right)^{\mathrm{e}}$ & 1.25 & $0.936(\ln )$ & $0.012-3.53$ & 8 \\
\hline
\end{tabular}

In lognormal distribution, $n$ normal distribution

${ }^{a}$ Twilley et al. 1992; Eong 1993; Matsui 1998; Kauffman et al. 2011; Donato et al. 2011; Ray et al. 2011; Donato et al. 2012

${ }^{\mathrm{b}}$ Komiyama et al. 1987; Twilley et al. 1992; Matsui 1998; Kauffman et al. 2011; Ray et al. 2011; Donato et al. 2012

${ }^{\mathrm{c}}$ Eong 1993; Matsui 1998; Kauffman et al. 2011; Ray et al. 2011; Donato et al. 2012; Lundstrum and Chen 2014

${ }^{d}$ Twilley et al. 1992; Amarasinghe and Balasubramaniam 1992; Eong 1993; Day et al. 1996; Middleton and McKee 2001; Jennerjahn and Ittekkot 2004; Guzman et al. 2005; Ray et al. 2011

${ }^{e}$ Twilley et al. 1992; Eong 1993; Duarte and Cabrián 1996; Chmura et al. 2003; Alongi 2008; Sanders et al. 2010; Ray et al. 2011; Mcleod et al. 2011 on the inputs of nitrogen into the ponds as feed or fertilizer. Hu et al. (2012), for example, assumed that $1.8 \%$ of the nitrogen input was converted to dinitrogen monoxide (as $\mathrm{N}_{2} \mathrm{O}-\mathrm{N}$, or $1.15 \%$ as $\mathrm{N}_{2} \mathrm{O}$ ). The IPCC (2014) also adopted the generic estimate of $1.69 \mathrm{~kg} \mathrm{~N}_{2} \mathrm{O}-\mathrm{N} \mathrm{t}^{-1}$ fish by $\mathrm{Hu}$ et al. (2012) for mangrove-integrated aquaculture. Since we know that most mixed mangrove shrimp farming systems are net removers of nitrogen (Jonell and Henriksson 2014), and that standing mangrove even potentially could be a net inhibitor of dinitrogen monoxide emissions (Allen et al. 2007), we here assume a precautions scenario of $1.67 \mathrm{~kg} \mathrm{~N}_{2} \mathrm{O}$ ha $^{-1}$ year $^{-1}(\mathrm{CV}=0.575$, $\ln )$.

\subsection{Greenhouse gas emissions from shrimp farming LULUC case study}

The analysis of historic land use identified only "mixed mangrove concurrent" shrimp farms being established in former mangrove areas (Table 5). It was assumed that these shrimp farms were the primary cause for the mangrove deforestation, as there were no indications of other activities on this land. Considering that only "mixed mangrove concurrent" shrimp farms were identified as causing mangrove deforestation, the related GHG emissions from mangrove LULUC were only calculated for this type of farming practice. Table 6 lists the GHG emissions per hectare per year for mixed mangrove concurrent shrimp farms.

The average mixed mangrove concurrent shrimp farm produces about $6.5 \mathrm{t}$ of shrimp by water area over 50 years. However, Asian tiger shrimp are not the only commodity produced in these ponds ( $\mathrm{Vu}$ et al. 2013; Jonell and Henriksson 2014), with only about $39.2 \%$ of the total output being Asian tiger shrimp by volume and $59.7 \%$ by value. The rest of the harvest consists of a mix of other shrimps, mud crabs, and other aquaculture products ( $\mathrm{Vu}$ et al. 2013; Jonell and Henriksson 2014). The GHG emissions from mangrove LULUC from shrimp farming were subsequently estimated to be $184 \mathrm{t} \mathrm{CO}_{2}$-eq $\mathrm{t}^{-1}$ live shrimp at farm gate using mass allocation and $282 \mathrm{t} \mathrm{CO}_{2}$-eq $\mathrm{t}^{-1}$ live shrimp using economic allocation (see ESM 2 for details on the calculations and

Table 4 Literature values

\begin{tabular}{|c|c|c|c|c|}
\hline System & Emission & Mean & Uncertainty estimate & Reference \\
\hline \multirow[t]{2}{*}{ Intact mangrove forest } & $\mathrm{kg} \mathrm{CH}_{4} \mathrm{ha}^{-2}$ year $^{-1}$ & 342 & $\mathrm{CV}=1.448(\ln )$ & Allen et al. 2007 \\
\hline & $\mathrm{kg} \mathrm{N}_{2} \mathrm{O}$ ha $^{-2}$ year $^{-1}$ & 1.67 & $\mathrm{CV}=0.575(\ln )$ & Allen et al. 2007 \\
\hline \multirow[t]{2}{*}{ Open aquaculture ponds } & $\mathrm{kg} \mathrm{CH}_{4} \mathrm{ha}^{-1}$ year $^{-1}$ & 533 & $\mathrm{CV}=0.40(\ln )$ & Astrudillo et al. 2015 \\
\hline & $\mathrm{N}_{2} \mathrm{O}-\mathrm{N}$ & $1.8 \%$ of $\mathrm{N}$ input & - & Hu et al. 2012 \\
\hline $\begin{array}{l}\text { Rewetted land, previously vegetated } \\
\text { by mangrove, salinity }<18 \mathrm{ppm}\end{array}$ & $\mathrm{kg} \mathrm{CH}_{4}$ ha $^{-1}$ year $^{-1}$ & 194 & $\mathrm{CV}=2.290(\ln )$ & IPCC 2014 \\
\hline $\begin{array}{l}\text { Rewetted land, previously vegetated } \\
\text { by mangrove, salinity }>18 \mathrm{ppm}\end{array}$ & $\mathrm{kg} \mathrm{CH}_{4} \mathrm{ha}^{-1}$ year $^{-1}$ & 0 & Range $=0-40$ (uniform) & IPCC 2014 \\
\hline
\end{tabular}


Table 5 Prior land uses affected by LUC in the case study, in combination with data derived from Google Earth (Google 2013), Global Land Cover by National Mapping Organizations (GLCNMO) (ISCGM 2003), Giri et al. (2011), and Murray et al. (2013)

\begin{tabular}{lccccc}
\hline & $\begin{array}{l}\text { Intensive } \\
\text { monoculture }\end{array}$ & $\begin{array}{l}\text { Semi-intensive } \\
\text { monoculture }\end{array}$ & $\begin{array}{l}\text { Improved } \\
\text { extensive }\end{array}$ & $\begin{array}{l}\text { Improved extensive } \\
\text { alternate }\end{array}$ & $\begin{array}{l}\text { Mixed mangrove } \\
\text { concurrent }\end{array}$ \\
\hline$n$ of farms & 17 & 51 & 20 & 6 & 11 \\
$\begin{array}{l}\text { Total number of } \\
\text { hectares }\end{array}$ & 250 & 105 & 26.8 & 10.9 & 35.5 \\
Mangrove & $0 \%$ & $0 \%$ & $0 \%$ & $0 \%$ & $100 \%$ \\
Aquaculture pond & $0 \%$ & $0 \%$ & $0 \%$ & $0 \%$ & $0 \%$ \\
Rice paddies & $18.4 \%$ & $41.4 \%$ & $100 \%$ & $76.1 \%$ & $0 \%$ \\
Forest land & $21.5 \%$ & $16.9 \%$ & $0 \%$ & $23.8 \%$ & $0 \%$ \\
Grassland & $48.1 \%$ & $24.8 \%$ & $0 \%$ & $0 \%$ & $0 \%$ \\
Cropland & $12.0 \%$ & $0 \%$ & $0 \%$ & $0 \%$ & $0 \%$ \\
Settlement & $0 \%$ & $17.0 \%$ & $0 \%$ & $0 \%$ & $100 \%$ \\
Total & $100 \%$ & $100 \%$ & $100 \%$ & $100 \%$ & \\
\hline
\end{tabular}

assumptions behind them). Noteworthy is that these LULUC emissions only apply to "mixed mangrove concurrent" shrimp farms, a farming practice that makes up less than $5 \%$ of the total shrimp production of Vietnam, and only about $1.2 \%$ global production (FAO FishstatJ 2014; Jonell and Henriksson 2014). Additionally, the analysis of 25 farms regarding their current land cover showed that this type of farming leaves an average of $39 \%(\mathrm{CV}=0.322$, range $16-69 \%)$ of the original mangrove forest intact within the farming premises, thus removing $61 \%$.

To put these LULUC emissions into proportion, they were compared with LCA emissions calculated by Henriksson et al. (2015). In their study, semi-intensive and intensive conventional shrimp farming both had global warming impacts of $13.2 \mathrm{t} \mathrm{CO}_{2}$-eq $\mathrm{t}^{-1}$ shrimp using mass allocation, and 4.7 and $5.1 \mathrm{t} \mathrm{CO}_{2}$-eq $\mathrm{t}^{-1}$ shrimp, respectively, using economic allocation (including $\mathrm{N}_{2} \mathrm{O}$ emissions from ponds). Given that these ponds had been aquaculture ponds for a long time, or converted from rice paddies, we can compare the importance of LULUC emissions from mixed mangrove shrimp (excluding LCA emissions) with those of a set of different system combinations (Table 7). As rice conversion of rice farms included the removal of sediments during pond construction, LUC emissions from $\Delta \beta \delta_{S}$ were therefor included. Comparing the different systems and prior land uses highlight the magnitude of LULUC emissions from mixed mangrove farms. Using mass allocation, a ton of Asian tiger shrimp from mixed mangrove systems would emit an order of magnitude more GHG emissions than from any of the other systems, a difference that is even starker using economic allocation.

\section{Discussion and conclusions}

\subsection{Methods and data for quantifying carbon dioxide emissions per hectare of mangrove deforested}

Despite the importance of mangrove forests for carbon capture and sequestration, there are still only a few available studies quantifying its carbon content and burial rates. This naturally induces uncertainty when calculating GHG emissions caused by LULUC. Part of the difference in the outcomes can be explained by the natural variation among different types of mangrove forests. Reported values for soil carbon content, for example, range from 186 to $1575 \mathrm{t} \mathrm{C} \mathrm{ha}^{-1}$ per $1.5 \mathrm{~m}$ depth. To be able to calculate more reliable global averages, there is a need for more data, as is emphasized by the large variances in the sensitivity results.

Relatively large differences in GHG emissions also arise from the assumptions on the depth and percentage of carbon in mangrove soils that is affected, although to a lesser degree. Following the IPCC (IPCC 2014) guidelines of 20-year annualization time and soil carbon loss of $1 \mathrm{~m}$ depth and $96 \%$ of carbon being oxidized would lead to estimates of $129 \mathrm{t} \mathrm{CO}_{2} \mathrm{ha}^{-1}$ year ${ }^{-1}$ deforested mangrove forest. However, in case of shrimp farming,
Table 6 GHG emissions as tons of $\mathrm{CO}_{2}$-equivalent including coefficients of variance from mangrove LULUC due to "mixed mangrove concurrent" shrimp farming per hectare and year annualized over 50 years

\begin{tabular}{llllllllll}
\hline Reference & $\Delta \beta_{A G}$ & $\Delta \beta_{B G}$ & $\Delta \beta_{L}$ & $\Delta \beta \delta_{S}$ & $\Delta \theta_{M P}$ & $\begin{array}{l}\text { Total } \\
\mathrm{CO}_{2}\end{array}$ & $\begin{array}{l}\mathrm{CH}_{4} \\
\text { emissions }\end{array}$ & $\begin{array}{l}\mathrm{N}_{2} \mathrm{O} \\
\text { emissions }\end{array}$ & $\begin{array}{l}\mathrm{Total}_{\mathrm{CO}} \mathrm{CO}^{-} \\
\mathrm{ha}^{-1} \mathrm{year}^{-1}\end{array}$ \\
\hline Average & 9.6 & 5.9 & 0.3 & 26.5 & 4.6 & 46.9 & 14.9 & 0.4 & 62.2 \\
$\mathrm{CV}$ & 0.467 & 1.503 & 0.268 & 0.601 & 0.903 & 0.409 & 0.400 & 0.575 & \\
\hline
\end{tabular}


Table 7 LULUC, methane, and dinitrogen oxide emissions from mixed mangrove, semi-intensive, and intensive farms for farming Asian tiger shrimps during 50 years compared to LCA

\begin{tabular}{|c|c|c|c|c|c|c|c|c|}
\hline System & $\begin{array}{l}\text { Allocation } \\
\text { factor }\end{array}$ & $\begin{array}{l}\text { Prior land } \\
\text { use }\end{array}$ & $\begin{array}{l}\text { t shrimp ha } \\
\text { water surface } \\
\text { area year }^{-1}\end{array}$ & $\begin{array}{l}\text { LULUC } \mathrm{t} \\
\mathrm{CO}_{2} \mathrm{t}^{-1} \\
\text { shrimp }\end{array}$ & $\begin{array}{l}\mathrm{LU} \mathrm{CH}_{4} \\
\text { emissions, } \mathrm{t} \mathrm{CO}_{2^{-}} \\
\text {eq } \mathrm{t}^{-1} \text { shrimp }\end{array}$ & $\begin{array}{l}\mathrm{LU} \mathrm{N}_{2} \mathrm{O} \\
\text { emissions, } \mathrm{kg} \\
\mathrm{CO}_{2} \text {-eq } \mathrm{t}^{-1} \text { shrimp }\end{array}$ & $\begin{array}{l}\text { Lifecycle } \\
\text { emissions, } \mathrm{t} \mathrm{CO}_{2^{-}} \\
\text {eq }^{-1} \text { shrimp }\end{array}$ & $\begin{array}{l}\text { Total, } \\
\mathrm{CO}_{2} \text {-eq t } \\
\text { shrimp }\end{array}$ \\
\hline $\begin{array}{l}\text { Mixed } \\
\text { mangrove }\end{array}$ & $\begin{array}{l}\text { Mass } \\
\quad(38.5 \%)\end{array}$ & Mangrove & 0.13 & 139 & 44.2 & 1.31 & & 184 \\
\hline Semi-intensive & $\begin{array}{l}\text { Mass } \\
\qquad(100 \%)\end{array}$ & $\begin{array}{l}\text { Aquaculture } \\
\text { pond }\end{array}$ & 6.6 & & 2.3 & Including in LCA & 13.2 & 15.5 \\
\hline Semi-intensive & $\begin{array}{l}\text { Mass } \\
\quad(100 \%)\end{array}$ & Rice paddy & 6.6 & 2.4 & 2.3 & Including in LCA & 13.2 & 21.5 \\
\hline Intensive & $\begin{array}{l}\text { Mass } \\
\quad(100 \%)\end{array}$ & $\begin{array}{l}\text { Aquaculture } \\
\text { pond }\end{array}$ & 7.6 & & 2.0 & Including in LCA & 13.2 & 15.2 \\
\hline Intensive & $\begin{array}{l}\text { Mass } \\
\quad(100 \%)\end{array}$ & Rice paddy & 7.6 & 2.1 & 2.0 & Including in LCA & 13.2 & 20.4 \\
\hline $\begin{array}{l}\text { Mixed } \\
\text { mangrove }\end{array}$ & $\begin{array}{l}\text { Eco } \\
\qquad(58.8 \%)\end{array}$ & Mangrove & 0.13 & 212 & 67.5 & 2 & & 282 \\
\hline Semi-intensive & $\begin{array}{l}\text { Eco } \\
\qquad(100 \%)\end{array}$ & $\begin{array}{l}\text { Aquaculture } \\
\text { pond }\end{array}$ & 6.6 & & 2.3 & Including in LCA & 4.7 & 7.0 \\
\hline Semi-intensive & $\begin{array}{l}\text { Eco } \\
\qquad(100 \%)\end{array}$ & Rice paddy & 6.6 & 2.4 & 2.3 & Including in LCA & 4.7 & 13.0 \\
\hline Intensive & $\begin{array}{l}\text { Eco } \\
\qquad(100 \%)\end{array}$ & $\begin{array}{l}\text { Aquaculture } \\
\text { pond }\end{array}$ & 7.6 & & 2.0 & Including in LCA & 5.1 & 7.1 \\
\hline Intensive & $\begin{array}{l}\text { Eco } \\
\qquad(100 \%)\end{array}$ & Rice paddy & 7.6 & 2.1 & 2.0 & Including in LCA & 5.1 & 12.3 \\
\hline
\end{tabular}

${ }^{\mathrm{a}}$ From Henriksson et al. (2015)

the soil is affected up to $1.5 \mathrm{~m}$ of depth while only $50 \%$ is oxidized and emissions are annualized over 50 years instead. This would in turn lead to $47 \mathrm{t} \mathrm{CO}_{2} \mathrm{ha}^{-1}$ year $^{-1}$ deforested mangrove forest. This shows how important it is to understand the consequences of different land uses on carbon stocks in mangrove soils. It also suggests that emissions from oxidized soil materials might also be relevant to consider when evaluating, i.e., the construction of Pangasius ponds (freshwater species not located in mangrove areas), as these normally are up to $4 \mathrm{~m}$ deep.

While carbon sequestration rates by mangrove forests nowadays are better understood and documented (Eong 1993; Duarte et al. 2005; Kauffman et al. 2011; Mcleod et al. 2011), they constituted another parameter with large data discrepancies. However, estimates of missed potential carbon sequestration were based on carbon build-up in the sediments that occurred over the past decades or even centuries (Eong 1993; Duarte et al. 2005; Mcleod et al. 2011). Choosing to ignore this unique property of mangrove forest would underestimate the global warming impact of mangrove LULUC with about $8 \%$. We therefore encourage further research to better understand the drivers behind carbon sequestration in mangrove forests and the influence of sea-level rise on these. We also stress the importance of quantifying uncertainties when considering LULUC emissions, as it is the only way to provide a level of confidence behind comparisons and it indicates that emissions can differ widely among locations, managements, and species of mangroves.

\subsection{Case study results}

The case study revealed the importance of including LULUC emissions when doing LCAs of systems that result in mangrove deforestation, to understand the full global warming impacts. Within the temporal frame of this study (2000-present), only mixed mangrove concurrent shrimp farming resulted in direct mangrove deforestation. Our calculations resulted in LULUC GHG emission estimations of $184 \mathrm{t} \mathrm{CO}_{2}$-eq t $\mathrm{t}^{-1}$ live shrimp at farm gate using mass allocation and $282 \mathrm{t} \mathrm{CO}_{2}$-eq $\mathrm{t}^{-1}$ live shrimp at farm gate using economic allocation of a mixed mangrove concurrent farm, with $68.0 \%$ originating from land-use change and $32.0 \%$ from land use. Amortized over 50 years, the emissions from mangrove LULUC were 24 to $37 \mathrm{t} \mathrm{CO}_{2}$-eq ha ${ }^{-1}$ year ${ }^{-1}$, which is far greater than other LCA emissions estimated for Vietnamese shrimp farms. It should be added that the calculations were based on the shrimp yield that was given per hectare of water area. As the patches of mangrove located within the pond area were therefore excluded from this value, we assumed $100 \%$ mangrove deforestation. However, it was noticed during the analysis of satellite data that many farmers had included these patches of mangrove land 
when reporting their total water area. This would thus mean that the emissions from mangrove deforestation resulting from shrimp farming would in practice be lower than those presented above. Moreover, the estimated single annual yield among intensive shrimp farmers were likely influenced by a disease outbreak, as shrimp farmers normally yield two, up to three, harvests per year.

Table 8 shows the extent to which this choice of timeframe directly influenced the results by varying the number of years over which the emissions were annualized. The present study based the timeframe within which the GHG emissions from mangrove LULUC were assigned to shrimp farming on the assumed life expectancy of the shrimp farm, which was 50 years. This resulted in 184 to $282 \mathrm{t} \mathrm{CO}_{2}$-eq $\mathrm{t}^{-1}$ of shrimp for mass and economic allocation, respectively, with $\mathrm{CO}_{2}$ from LUC accounting for $68.0 \%$ of the total emissions, $\mathrm{CO}_{2}$ from $\mathrm{LU}$ for $7.4 \%, \mathrm{CH}_{4}$ emissions for $24.0 \%$, and $\mathrm{N}_{2} \mathrm{O}$ emissions for $0.7 \%$. Fifty years seemed like a logical choice to consider all shrimp produced as equal contributors to the deforestation, based on the data on the life expectancy of farms. However, it is common practice to set the timeframe to a prefixed number of years. Following, i.e., the IPCC (2006) default recommendation of 20 years would lead to 372.2 to $568.5 \mathrm{t} \mathrm{CO}_{2}$-eq $\mathrm{t}^{-1}$ of shrimp for mass and economic allocation, respectively. In this case, $\mathrm{CO}_{2}$ from LUC would account for $81.4 \%$ of the total emissions, $\mathrm{CO}_{2}$ from $\mathrm{LU}$ for $3.6 \%, \mathrm{CH}_{4}$ for $11.9 \%$, and $\mathrm{N}_{2} \mathrm{O}$ for $0.4 \%$. Naturally, the shorter the timeframe, the higher the GHG emissions per ton of shrimp and the higher the contribution of $\mathrm{LUC} \mathrm{CO}_{2}$ emissions, which is why it is important to understand these implications and choose a realistic timeframe corresponding to current knowledge on shrimp farming.

Noteworthy is that the displacement of some prior land uses, such as agricultural fields, might result in these farms relocating elsewhere and consequently causing additional forest lost. Richards and Friess (2015), for example, allocated the loss of 55.4 ha of mangrove towards new rice farms between 2000 and 2012, while aquaculture farms were responsible for roughly the double (111.8 ha). The overall rice paddy area, in the main time, increased by 95,000 ha, an increase of $1.2 \%$ of the overall rice paddy area (FAO 2016), compared to a $265 \%$ increase in the farmed shrimp production during the same period. Thus, the interplay of marginal demands for land is complex and could not be explored within the context of the present research.

According to the Protection Forest Management Boards, families practicing mixed mangrove concurrent shrimp farming are allowed to use up to $30 \%$ of the land and surface water for their own purposes to generate income (McNally et al. 2010). According to satellite photos, however, an average of $61 \%$ of the mangrove forest was removed from pond areas. It is therefore debatable if mixed mangrove concurrent shrimp farming protects mangrove forests as effectively as originally intended. On the other hand, these farms only make up a small share of overall shrimp production in Vietnam, and only 25 farms in two provinces were evaluated. Moreover, satellite imagery only dated back to the year 2000, and the images only provide rough estimates of vegetation types, while most
Table 8 Results for GHG emissions as $\mathrm{CO}_{2}$-equivalent from mangrove LULUC due to shrimp farming in the "mixed mangrove concurrent" farming system, per ton of live shrimp over different time frames

\begin{tabular}{|c|c|c|c|c|c|c|}
\hline & $\begin{array}{l}\mathrm{t} \mathrm{CO}_{2} \text {-eq t } \\
\text { shrimp }\end{array}$ & Years & & & & \\
\hline & & 10 & 20 & 50 & 100 & 200 \\
\hline \multicolumn{7}{|c|}{ Mass allocation } \\
\hline \multirow[t]{3}{*}{$\mathrm{LU}$} & $\mathrm{CO}_{2}$ & $13.6(2.0 \%)$ & $13.6(3.6 \%)$ & $13.6(7.4 \%)$ & $\begin{array}{r}13.6 \\
(11.1 \%)\end{array}$ & $\begin{array}{r}13.6 \\
(15.0 \%)\end{array}$ \\
\hline & $\mathrm{CH}_{4}$ & $44.2(6.4 \%)$ & $44.2(11.9 \%)$ & $44.2(24.0 \%)$ & $\begin{array}{r}44.2 \\
(36.3 \%)\end{array}$ & $\begin{array}{r}44.2 \\
(48.9 \%)\end{array}$ \\
\hline & $\mathrm{N}_{2} \mathrm{O}$ & $1.3(0.2 \%)$ & $1.3(0.4 \%)$ & $1.3(0.7 \%)$ & $1.3(1.1 \%)$ & $1.3(1.4 \%)$ \\
\hline LUC & $\mathrm{CO}_{2}$ & $\begin{array}{r}626.3 \\
(91.4 \%)\end{array}$ & $\begin{array}{r}313.2 \\
(84.1 \%)\end{array}$ & $\begin{array}{r}125.3 \\
(68.0 \%)\end{array}$ & $\begin{array}{r}62.6 \\
(51.5 \%)\end{array}$ & $\begin{array}{r}31.3 \\
(34.6 \%)\end{array}$ \\
\hline LULUC & $\mathrm{CO}_{2}$-eq & 685.4 & 372.2 & 184.3 & 121.7 & 90.4 \\
\hline \multicolumn{7}{|c|}{ Economic allocation } \\
\hline \multirow[t]{3}{*}{ LU } & $\mathrm{CO}_{2}$ & $20.7(2.0 \%)$ & $20.7(3.6 \%)$ & $20.7(7.4 \%)$ & $\begin{array}{r}20.7 \\
(11.1 \%)\end{array}$ & $\begin{array}{r}20.7 \\
(15.0 \%)\end{array}$ \\
\hline & $\mathrm{CH}_{4}$ & $67.5(6.4 \%)$ & $67.5(11.9 \%)$ & $67.5(24.0 \%)$ & $\begin{array}{r}67.5 \\
(36.3 \%)\end{array}$ & $\begin{array}{r}67.5 \\
(48.9 \%)\end{array}$ \\
\hline & $\mathrm{N}_{2} \mathrm{O}$ & $2.0(0.2 \%)$ & $2.0(0.4 \%)$ & $2.0(0.7 \%)$ & $2.0(1.1 \%)$ & $2.0(1.4 \%)$ \\
\hline LUC & $\mathrm{CO}_{2}$ & $\begin{array}{r}956.6 \\
(91.4 \%)\end{array}$ & $\begin{array}{r}478.3 \\
(84.1 \%)\end{array}$ & $\begin{array}{r}191.3 \\
(68.0 \%)\end{array}$ & $\begin{array}{r}95.7 \\
(51.5 \%)\end{array}$ & $\begin{array}{r}47.8 \\
(34.6 \%)\end{array}$ \\
\hline LULUC & $\mathrm{CO}_{2}$-eq & 1046.8 & 568.5 & 281.5 & 185.9 & 138.1 \\
\hline
\end{tabular}


deforestation in Vietnam happened during the 1980s and 1990s (WWF 2013; Richards and Friess 2015). Despite this, agencies promoting these systems (i.e., Naturland) need to reevaluate their environmental sustainability, especially in countries where this type of shrimp farming is more common, including Indonesia (DasGupta and Shaw 2013; Richards and Friess 2015).

As mentioned before, research on methane emissions resulting from land use of mangrove area is rather limited and most research on methane fluxes focus on integrated rice-fish ponds (Frei and Becker 2005; Datta et al. 2009) or other human disturbances of mangroves (i.e., Konnerup et al. 2014). The pond conditions in the IAA systems, which were used as a proxy for methane emissions in this study, came closest to those found in the mixed mangrove concurrent systems (Astudillo et al. 2015). However, emissions are highly influenced by farming practices (including aeration, feed use, co-stocked species, and fertilization) and environmental conditions (including salinity, oxygen levels, and temperature) (Alongi 2005; Howe et al. 2009; Penha-Lopes et al. 2010; Astudillo et al. 2015). For example, the presence of sulfates in mangrove systems would limit the activity of methanogenesis (Howe et al. 2009), thereby lowering the methane emissions for the mixed mangrove system compared to the IAA system. It is therefore important to remember that our results for methane emissions are only a first proxy of the potential magnitude of the emissions, and we therefore urge for more research on this topic.

Despite the limitations highlighted above, our worst-case estimates are not even close to those presented by Kauffman (Stokstad 2012), who estimated the LULUC emissions due to shrimp farming to be $198 \mathrm{~kg} \mathrm{CO}_{2}$ per $100 \mathrm{~g}$ shrimp tail or $1307 \mathrm{t} \mathrm{CO}_{2} \mathrm{t}^{-1}$ shrimp (assuming an edible yield of $34 \%$; Louisiana Direct Seafood 2011; Zirlotts Gulf Products 2013), more than four times higher than our highest estimate. Kauffman's calculations differ from ours mainly in different assumptions regarding the percentage of shrimp farms constructed in former mangrove areas (50-60\%), early abandonment of farms (after 3-9 years), and an annual production of just 50 to $500 \mathrm{~kg} \mathrm{ha}^{-1}$ for the average shrimp farm (Stokstad 2012). Kauffman's assumptions on early abandonment of farms can lead to the high climate warming impact, as the emissions are attributed to only a few years of shrimp farming yields. In contrast, our study found that a mere fraction of shrimp come from farms located in former mangrove areas, that management has improved to a point where farming can be maintained for 50 years or more (Jonell and Henriksson 2014), that only $39.2 \%$ of the pond mass output of extensive mixed mangrove farming is shrimp, and that even these farms produce $0.13 \mathrm{t}$ shrimp ha ${ }^{-1}$ year $^{-1}$ on average (Murray et al. 2013).

Important to highlight is that GHG emissions are only one of the many environmental concerns associated with shrimp farming. Others include loss of biodiversity, eutrophication, freshwater ecotoxicity, overexploitation of juveniles, acidification, and photochemical oxidation (Jonell and Henriksson 2014). LCAs including LULUC therefore also consider such environmental impacts. In the process of doing so, the structure of the mangrove removal should be taken into consideration, as it could be argued that partial removal, as is done in mixed mangrove farms, may leave enough mangrove to buffer eutrophying emissions (Jonell and Henriksson 2014). Moreover, ecosystem services maintained by preserving part of the forest should not be neglected, as phenomena like tsunamis and typhoons are commonplace in SE Asia. Securing a livelihood in return for partial protection of the mangrove may therefore help to conserve the remaining mangrove forests, if properly managed. Such socio-ecological trade-offs surely need to be considered before making any policy decisions since long-term protection of the remaining mangroves in Asia is of the utmost importance.

Nonetheless, the results of our case study of shrimp farming in mangrove areas show how huge mangrove LULUC emissions can be compared with similar emissions from other activities in the shrimp farming value chain (i.e., feed provision and electricity generation). Despite uncertainties and limitations in the underlying data, the sheer magnitude of the emissions shows that excluding mangrove LULUC emissions from LCA studies most certainly leads to a severe underestimation of the actual GHG emissions.

Acknowledgements In memoriam of Prof. Dr. Ir. Gerard PJ Dijkema who was central to the early stages of shaping this research.

This work has been done as part of the Master Industrial Ecology of Leiden University/Technical University Delft and has built on results of the Sustaining Ethical Aquaculture Trade (SEAT) project, which was cofunded by the European Commission within the Seventh Framework Programme - Sustainable Development Global Change and Ecosystem (Project 222889); www.seatglobal.eu.

\section{Compliance with ethical standards}

Conflict of interest The authors declare that they have no conflict of interest.

Open Access This article is distributed under the terms of the Creative Commons Attribution 4.0 International License (http:// creativecommons.org/licenses/by/4.0/), which permits unrestricted use, distribution, and reproduction in any medium, provided you give appropriate credit to the original author(s) and the source, provide a link to the Creative Commons license, and indicate if changes were made.

\section{References}

Allen DE, Dalal RC, Rennenberg H, Meyer RL, Reeves S, Schmidt S (2007) Spatial and temporal variation of nitrous oxide and methane flux between subtropical mangrove sediments and the atmosphere. Soil Biol Biochem 39(2):622-631 
Alongi DM (2005) Mangrove-microbe-soil relations. In: Interactions between macro- and microorganisms in marine sediments. American Geophysical Union, pp 85-103

Alongi DM (2008) Mangrove forests: resilience, protection from tsunamis, and responses to global climate change. Estuar Coast Shelf Sci 76:1-13

Amarasinghe MD, Balasubramaniam S (1992) Net primary productivity of two mangrove forest stands on the northwestern coast of Sri Lanka. Hydrobiologia 247:37-47

Astudillo MF, Thalwitz G, Vollrath F (2015) Modern analysis of an ancient integrated farming arrangement: life cycle assessment of a mulberry dyke and pond system. Int J Life Cycle Assess 20:13871398

Béland M, Goïta K, Bonn F, Pham TTH (2006) Assessment of land-cover changes related to shrimp aquaculture using remote sensing data: a case study in the Giao Thuy District, Vietnam. Int J Remote Sens 27: $1491-1510$

Bouillon S, Borges AV, Castañeda-Moya E et al (2008) Mangrove production and carbon sinks: a revision of global budget estimates. Glob Biogeochem Cycles. doi:10.1029/2007GB003052

Cederberg C, Persson UM, Neovius K et al (2011) Including carbon emissions from deforestation in the carbon footprint of Brazilian beef. Environ Sci Technol 45:1773-1779

Chmura GL, Anisfeld SC, Cahoon DR, Lynch JC (2003) Global carbon sequestration in tidal, saline wetland soils. Glob Biogeochem Cycles. doi:10.1029/2002GB001917

DasGupta R, Shaw R (2013) Cumulative impacts of human interventions and climate change on mangrove ecosystems of south and Southeast Asia: an overview. J Ecosyst 2013:1-15

Datta A, Nayak DR, Sinhababu DP, Adhya TK (2009) Methane and nitrous oxide emissions from an integrated rainfed rice-fish farming system of eastern India. Agric Ecosyst Environ 129:228-237

Day JW Jr, Coronado-Molina C, Vera-Herrera FR et al (1996) A 7 year record of above-ground net primary production in a southeastern Mexican mangrove forest. Aquat Bot 55:39-60

Donato DC, Kauffman JB, Murdiyarso D et al (2011) Mangroves among the most carbon-rich forests in the tropics. Nat Geosci 4:293-297

Donato DC, Kauffman JB, Mackenzie RA et al (2012) Whole-island carbon stocks in the tropical pacific: implications for mangrove conservation and upland restoration. J Environ Manag 97:89-96

Duarte CM, Cabrián J (1996) The fate of marine autotrophic production. Limnol Oceanogr 41:1758-1766

Duarte CM, Middelburg JJ, Caraco N (2005) Major role of marine vegetation on the oceanic carbon cycle. Biogeosciences 2:1-8

Eong OJ (1993) Mangroves - a carbon source and sink. Chemosphere 27:1097-1107

FAO (2005) Cultured aquatic species information programme: Penaeus monodon. http://www.fao.org/fishery/culturedspecies/Penaeus monodon/en. Accessed 17 Jul 2013

FAO (2007) Mangrove trees and shrubs of the Maldives. Bangkok, Thailand

FAO (2016) FAOSTAT database. http://www.fao.org/faostat/en/\#home. Accessed 1 Dec 2016

FAO FishstatJ (2014) FishstatJ—software for fishery statistical time series. http://www.fao.org/fishery/statistics/software/fishstatj/en. Accessed 10 Sep 2015

Frei M, Becker K (2005) Integrated rice-fish production and methane emission under greenhouse conditions. Agric Ecosyst Environ 107:51-56

Giri C, Ochieng E, Tieszen LL et al (2011) Status and distribution of mangrove forests of the world using earth observation satellite data. Glob Ecol Biogeogr 20:154-159

Global Aquaculture Alliance (2012) Dated, erroneous assumptions yield misleading "Carbon Footprint" for farmed shrimp. http://www. gaalliance.org/newsroom/news.php?Dated-Erroneous-
Assumptions-Yield-Misleading-Carbon-Footprint-For-FarmedShrimp-59. Accessed 1 Aug 2013

Google (2013) Google Earth. http://www.google.com/earth/index.html. Accessed 15 Dec 2015

Guzman HM, Barnes PAG, Lovelock CE, Feller IC (2005) A site description of the CARICOMP mangrove, seagrass and coral reef sites in the Bocas del Toro, Panama. Caribb J Sci 41:430-440

Henriksson PJG, Guinée JB, Kleijn R, de Snoo GR (2012) Life cycle assessment of aquaculture systems - a review of methodologies. Int J Life Cycle Assess 17:304-313

Henriksson PJG, Rico A, Zhang W et al (2015) Comparison of Asian aquaculture products by use of statistically supported life cycle assessment. Environ Sci Technol 49:14176-14183

Hong PN, Dao QTQ (2004) Environmental impact of shrimp culture in the mangrove areas of Vietnam. Annual Report of FY 2003, The Core University Program between Japan Society for the Promotion of Science (JSPS) and National Centre for Natural Science and Technology (NCST). Hanoi, Vietnam

Howe AJ, Rodríguez JF, Saco PM (2009) Surface evolution and carbon sequestration in disturbed and undisturbed wetland soils of the hunter estuary, southeast Australia. Estuar Coast Shelf Sci 84:75-83

$\mathrm{Hu}$ Z, Lee JW, Chandran K et al (2012) Nitrous oxide $\left(\mathrm{N}_{2} \mathrm{O}\right)$ emission from aquaculture: a review. Environ Sci Technol 46:6470-6480

IPCC (2006) 2006 IPCC Guidelines for National Greenhouse Gas Inventories, Prepared by the National Greenhouse Gas Inventories Programme. Eggleston HS, Buendia L, Miwa K, Ngara T, Tanabe K (eds), Japan

IPCC (2014) 2013 Supplement to the 2006 IPCC Guidelines for National Greenhouse Gas Inventories: Wetlands. Hiraishi, T, Krug, T, Tanabe, K, Srivastava, N, Baasansuren, J, Fukuda, M and Troxler, TG (eds). Switzerland

ISCGM (2003) Land Cover (GLCNMO) - global version. http://www. iscgm.org $/ \mathrm{gm} / \mathrm{glcnmo.html}$. Accessed 24 Jun 2013

ISO (2006) Environmental management-Life cycle assessmentRequirements and guidelines. International Standard ISO 14044; International Organisation for Standardisation: Geneva, Switzerland

Jennerjahn TC, Ittekkot V (2004) Relevance of mangroves for the production and deposition of organic matter along tropical continental margins. Naturwissenschaften 89:23-30

Jonell M, Henriksson PJG (2014) Mangrove-shrimp farms in Vietnamcomparing organic and conventional systems using life cycle assessment. Aquaculture. doi:10.1016/j.aquaculture.2014.11.001

Kauffman JB, Heider C, Cole TG et al (2011) Ecosystem carbon stocks of Micronesian mangrove forests. Wetlands 31:343-352

Komiyama A, Ogina K, Aksornkoae S, Sabhasri S (1987) Root biomass of a mangrove forest in southern Thailand. 1. Estimation by the trench method and the zonal structure of root biomass. J Trop Ecol 3:97-108

Konnerup D, Betancourt-Portela JM, Villamil C, Parra JP (2014) Nitrous oxide and methane emissions from the restored mangrove ecosystem of the Ciénaga Grande de Santa Marta, Colombia. Estuar Coast Shelf Sci 140:43-51

Kristensen E, Bouillon S, Dittmar T, Marchand C (2008) Organic carbon dynamics in mangrove ecosystems: a review. Aquat Bot 89:201-219

Lebel L, Tri NH, Saengnoree A et al (2002) Industrial transformation and shrimp aquaculture in Thailand and Vietnam: pathways to ecological, social, and economic sustainability? Ambio 31:311-323

Lebel L, Mungkung RT, Gheewala SH, Lebel P (2010) Innovation cycles, niches and sustainability in the shrimp aquaculture industry in Thailand. Environ Sci Pol 13:291-302

Louisiana Direct Seafood (2011) Seafood handbook: Shrimp story. http:// louisianadirectseafood.com/handbook. Accessed 22 Jun 2013

Lovelock CE (2008) Soil respiration and belowground carbon allocation in mangrove forests. Ecosystems 11:342-354

Lundstrum A, Chen L (2014) Soil carbon stocks and accumulation in young mangrove forests. Soil Biol Biochem 75:223-232 
Matsui N (1998) Estimated stocks of organic carbon in mangrove roots and sediments in Hinchinbrook channel, Australia. Mangroves salt marshes 2:199-204

Mcleod E, Chmura GL, Bouillon S et al (2011) A blueprint for blue carbon: toward an improved understanding of the role of vegetated coastal habitats in sequestering $\mathrm{CO}_{2}$. Front Ecol Environ 9:552-560

McNally R, McEwin A, Holland T (2010) The potential for mangrove carbon projects in Vietnam. Netherlands

Middleton BA, McKee KL (2001) Degradation of mangrove tissues and implications for peat formation in Belizean island forests. J Ecol 89: $818-828$

Mungkung RT (2005) Shrimp aquaculture in Thailand: application of life cycle assessment to support sustainable development, $\mathrm{PhD}$ thesis

Murray BC, Watt CE, Cooley DM, Pendleton LH (2012) Coastal Blue Carbon and the United Nations Current Status and Future Directions; Policy brief

Murray FJ, Haque MM, Zhang W et al (2013) Defining boundaries towards understanding sustainable ethical aquaculture trade between Asia and Europe. SEAT Project Report 2.8. Stirling, UK

National Oceanic and Atmospheric Administration-Earth System (2010) Mangrove ecology. In: Encycl. Earth. http://www.eoearth.org/ article/Mangrove_ecology?topic=49514. Accessed 28 Jun 2013

Penha-Lopes G, Kristensen E, Flindt M et al (2010) The role of biogenic structures on the biogeochemical functioning of mangrove constructed wetlands sediments - a mesocosm approach. Mar Pollut Bull 60:560-572

Phan LT, Nguyen PT, Murray FJ, Little CD (2011) Development trends and local sustainability perceptions for the international trade in seafood farmed in Vietnam. Deliverable 2.1c of the SEAT project. Stirling, UK

Ray R, Ganguly D, Chowdhury C et al (2011) Carbon sequestration and annual increase of carbon stock in a mangrove forest. Atmos Environ 45:5016-5024

Richards DR, Friess DA (2015) Rates and drivers of mangrove deforestation in Southeast Asia, 2000-2012. Proc Natl Acad Sci USA Early Edit:1-6. doi: 10.1073/pnas.1510272113

Rönnbäck P (1999) The ecological basis for economic value of seafood production supported by mangrove ecosystems. Ecol Econ 29:235-252

Sanders CJ, Smoak JM, Naidu AS et al (2010) Organic carbon burial in a mangrove forest, margin and intertial mud flat. Esturine, Coast Shelf Sci 30:168-172

Schmidinger K, Stehfest E (2012) Including $\mathrm{CO}_{2}$ implications of land occupation in LCAs - method and example for livestock products. Int J Life Cycle Assess 17:962-972

Stokstad E (2012) The carbon footprint of a shrimp cocktail. In: AAAS, Sci. News. http://news.sciencemag.org/earth/2012/02/carbonfootprint-shrimp-cocktail. Accessed 7 Sep 2015

Twilley RR, Chen RH, Hargis T (1992) Carbon sinks in mangroves and their implications to carbon budget of tropical coastal ecosystems. Water Air Soil Pollut 64:265-288

Vu TA, Phan LT, Do H Van et al (2013) Status of small-scale environmentally friendly shrimp production in Ca Mau Province, Viet Nam

WWF (2013) Ecosystems in the Greater Mekong. Past trends, current status, possible futures; WWF report Greater Mekong

Zirlotts Gulf Products (2013) Shrimp. http://www.zirlottseafood.com/ store/shrimp.html. Accessed 22 Jun 2013 